\title{
An Experimental Study in Simulated Greenroof in Mediterranean
}

\section{Climate}

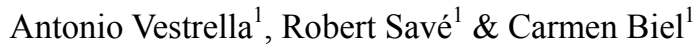 \\ ${ }^{1}$ IRTA, (Research and Technology, Food and Agriculture Institute) Torre Marimon, Caldes De Montbui, \\ Barcelona, Spain \\ Correspondence: Antonio Vestrella, IRTA, (Research and Technology, Food and Agriculture Institute) Torre \\ Marimon, 08140, Caldes De Montbui, Barcelona, Spain. E-mail: antoniovestrella@gmail.com
}

Received: January 7, $2015 \quad$ Accepted: February 8, $2015 \quad$ Online Published: March 15, 2015
$\begin{aligned} & \text { doi:10.5539/jas.v7n4p95 } \\ & \text { URL: http://dx.doi.org/10.5539/jas.v7n4p95 }\end{aligned}$

\begin{abstract}
The use of green roofs in the Mediterranean area is becoming more widespread. Use of the species which are most commonly used across the world can be limited by the specific conditions of the Mediterranean climate. An experimental green roof simulation tested the performance of 12 species divided into three groups according to growth form (ground cover, sub-shrub, rhizomatous-herbaceous). Different irrigation criteria were applied to each group: in two sections potential evapotranspiration (ET0) levels of $20 \%$ and $40 \%$ were applied, while the third section was rainfed. Mortality, green coverage, blooming and final biomass were measured.

The amount of water received and the low winter temperatures affected plant mortality. Significant differences in coverage were observed when comparing the rainfed section with the two irrigated areas. Ground cover plants in the irrigated sections achieved the best results in terms of coverage. Significant differences in biomass were observed only when comparing the irrigated plots with the rainfed plot. The influence of different irrigation protocols on flowering was observed in five species only.

The growth form groups responded in different ways to drought stress: rhizomatous-herbaceous developed slowly and consistently; ground cover developed quickly and relied more on the water supply; sub-shrubs showed lower resistance to drought stress under the present experimental conditions. Of the 12 plants tested for green-roof adaptation in a Mediterranean climate, those which performed best were: Centranthus ruber (L.) DC., Santolina rosmarinifolia L., Helichrysum stoechas (L.) Moench, Iris lutescens Lam..
\end{abstract}

Keywords: green roofs, drought stress, green coverage, mortality, flowering

\section{Introduction}

The remarkable growth of green roofing in Central and Northern Europe in recent years has not been followed by similar developments in nearby Mediterranean countries. Green roof experiments first took place in Germany in 1950, and other countries followed during the 1970s (Köhler, 2006). In 1982, the German Landscape Research, Development and Construction Society (FLL) published regulatory guidelines for green roofing (FLL, 2008). Many technical aspects of the issue have subsequently been investigated, with the aim of improving the efficiency of these systems with designs for lighter and safer materials and for reduced building costs. At the same time, urban ecology studies have looked at the impact of green roofs in terms of urban biodiversity (Lundholm, 2006; Bass, 2009; Lundholm \& Peck, 2008; Oberndorfer et al., 2007), energy consumption (Andersson, 2006; Carter \& Butler, 2008; Abram, 2011; Spala et al., 2008) and the psychological and social impact on individuals and small communities (Samangooei, 2006; So-Young et al., 2008). Over the past few years the use of green roofs has spread to Italy and Spain and other areas with continental and atlantic climates, but only very recently have green roofs begun to spread to Mediterranean coastal areas (Abram, 2006; Briz Escribano, 2004; Neila et al., 2008; Damas et al., 2010).

The genus Sedum represents the most widely used plant species in Mediterranean green roofs across the world. The species of this genus do perform well in terms of survival rate, but they can lack homogeneity of coverage, and have low growth rates and poor biodiversity. Studies have shown that a combination of different species results in improved resilience under stress conditions when compared to mono-species cultivations (Gedge \& Kadas, 2005; Lundholm et al., 2010; Nagase \& Dunnet, 2010; Bretzel et al., 2011). 
Effectively combining different species in extensive Mediterranean green roofs is not an easy task. They should be selected for adaptability to the Mediterranean bioclimate as well as to urban environments, and to environmental conditions specific to green roofs (drought, poor nutrients, high temperature stress) (Caneva et al., 2013; Papafotiou et al., 2013). The species should also have low allergenicity, attract insects and birds, and display ornamental and aesthetic characteristics throughout the seasons (Benvenuti \& Bacci, 2010; Provenzano et al., 2010; Brenneisen, 2006).

The urban planners of many cities integrate green roofs into the design of their ecological corridor projects, since they represent an effective method with which to extend green surface areas and increase biodiversity (Agencia de Ecología Urbana de Barcelona, 2010; Ajuntament de Barcelona, 2010; Carter \& Butler, 2008; Damas et al., 2010; Lundholm \& Peck, 2008). The aim of this study is to analyse the ecological behaviour of twelve plant species, which have been grouped into three different categories by taking into account their growth patterns and evaluating their performance under three different irrigation protocols (two protocols applying minimum watering and one with none) in a Mediterranean environment.

\section{Materials and Methods}

\subsection{Study Site}

The trials were carried out in Caldes de Montbui (205 m.a.s.1.) $\left(41^{\circ} 63^{\prime} \mathrm{N} 2^{\circ} 16^{\prime} \mathrm{E}\right)$ - $30 \mathrm{~km}$ from Barcelona (Spain), where the Catalan mountains meet the Mediterranean coast. During the trial period (June 2009-May 2010) average monthly temperatures were between $6.1^{\circ} \mathrm{C}$ and $25.1^{\circ} \mathrm{C}$. Average monthly rainfall was between $5.2 \mathrm{~mm}$ and $125.2 \mathrm{~mm}$, potential evapotranspiration (ET0) ranged from $20.4 \mathrm{~mm}$ to $139.7 \mathrm{~mm}$. High ET0 values were recorded during summer when rainfall was scarce. In June, ET0 reached $135.3 \mathrm{~mm}$ with precipitation up to 10.7 $\mathrm{mm}$. In July maximum ET0 was $139.7 \mathrm{~mm}$, with maximum precipitation at $10.7 \mathrm{~mm}$. In August it only rained once, for a total of $27.4 \mathrm{~mm}$, and ET0 reached $131 \mathrm{~mm}$. Between June 2009 and May 2010 a total of $640 \mathrm{~mm}$ precipitation and $925 \mathrm{~mm}$ ET0 were recorded. Unusually, temperature values in December 2009 and March 2010 fell below $0{ }^{\circ} \mathrm{C}$, reaching $-8{ }^{\circ} \mathrm{C}$ and damaging some species while destroying others. Evapotranspiration values (for the calculation of irrigation patterns) and all other climate data was provided by the Caldes de Montbui weather station, located $150 \mathrm{~m}$ from the site of the experiment. Table 1 shows climate data related to the trial period along with a summary of the period between 1991 and 2010. 
Table 1. Climatic monthly averages and absolute data* during the trial period (June 2009 - May 2010) and during the twenty year period from 1991 to 2010 (historic monthly climate data*)

\begin{tabular}{|c|c|c|c|c|c|c|c|c|}
\hline \multirow{2}{*}{ Monthly data } & & \multicolumn{3}{|c|}{ Temp. $\left({ }^{\circ} \mathrm{C}\right)$} & \multicolumn{2}{|c|}{ Absolute Temp. $\left({ }^{\circ} \mathrm{C}\right)$} & \multirow{2}{*}{ Rainfall (mm) } & \multirow{2}{*}{$\mathrm{ETO}(\mathrm{mm})$} \\
\hline & & Mean & Max & Min & Max & Min & & \\
\hline Trial period & JUN 09 & 22.4 & 29.2 & 15.6 & 35 & 11.8 & 10.7 & 135.3 \\
\hline Historic (1991-2010) & JUN & 21.0 & 27.3 & 14.7 & 33.8 & 9.1 & 44.6 & 124.9 \\
\hline Trial period & JUL 09 & 24.2 & 30.3 & 17.9 & 37.2 & 11.4 & 11.6 & 139.7 \\
\hline Historic (1991-2010) & JUL & 23.5 & 29.7 & 17.2 & 35.4 & 11.5 & 24.7 & 130.5 \\
\hline Trial period & AUG 09 & 25.0 & 31.8 & 19.0 & 37.4 & 16.8 & 27.4 & 131.0 \\
\hline Historic (1991-2010) & AUG & 22.4 & 28.2 & 16.8 & 33.6 & 11.0 & 50.7 & 120.7 \\
\hline Trial period & SEP 09 & 20.2 & 26.5 & 14.8 & 30 & 10.9 & 103.4 & 85.5 \\
\hline Historic (1991-2010) & SEP & 18.9 & 24.6 & 13.8 & 31.2 & 7.7 & 89.1 & 77.3 \\
\hline Trial period & OCT 09 & 16.5 & 23.1 & 11.2 & 29.3 & 3.6 & 72.2 & 62.6 \\
\hline Historic (1991-2010) & OCT & 15.7 & 21.5 & 10.9 & 27.7 & 3.7 & 81.9 & 53.1 \\
\hline Trial period & NOV 09 & 11.7 & 18.4 & 6.6 & 25 & 2 & 5.2 & 34.0 \\
\hline Historic (1991-2010) & $\mathrm{NOV}$ & 10.1 & 16.4 & 5.0 & 22.3 & -1.2 & 39.9 & 25.9 \\
\hline Trial period & DEC 09 & 7.4 & 13.0 & 2.8 & 19.2 & -7.9 & 47.5 & 20.4 \\
\hline Historic (1991-2010) & $\mathrm{DEC}$ & 7.2 & 13.4 & 2.4 & 19.1 & -3.4 & 52.2 & 16.5 \\
\hline Trial period & JAN 10 & 6.2 & 10.8 & 2.5 & 16.5 & -3.1 & 59 & 24.5 \\
\hline Historic (1991-2010) & JAN & 6.7 & 13.5 & 1.4 & 19.6 & -4.0 & 40.4 & 22.3 \\
\hline Trial period & FEB 10 & 7.0 & 12.4 & 1.9 & 18 & -5.9 & 89.5 & 36.6 \\
\hline Historic (1991-2010) & FEB & 7.7 & 14.7 & 1.9 & 20.0 & -2.8 & 29.2 & 31.3 \\
\hline Trial period & MAR 10 & 8.8 & 14.7 & 3.4 & 20.9 & -4.4 & 66 & 66.4 \\
\hline Historic (1991-2010) & MAR & 10.5 & 17.2 & 4.4 & 24.4 & -1.2 & 33.0 & 58.2 \\
\hline Trial period & APR 10 & 12.9 & 19.4 & 7.0 & 25.6 & 3.6 & 32.8 & 86.3 \\
\hline Historic (1991-2010) & APR & 12.8 & 19.3 & 6.6 & 25.8 & 1.3 & 50.0 & 79.1 \\
\hline Trial period & MAY 10 & 15.3 & 21.2 & 9.6 & 30.1 & 4.1 & 125.2 & 106.9 \\
\hline Historic (1991-2010) & MAY & 16.7 & 22.8 & 10.6 & 29.8 & 4.6 & 63.6 & 112.9 \\
\hline
\end{tabular}

Note. ${ }^{*}$ from the weather station of Caldes de Montbui (MeteoCat http://www.meteo.cat/servmet/radar/).

\subsection{Simulation of a Green Roof System}

The conditions found on extensive green roofs were replicated by constructing walled containers with prefabricated concrete panels. The other materials used were produced by ZinCo®: the container was covered with a synthetic water-retentive polypropylene SSM45 protection mat, having a water-retention capacity of approximately $5 \mathrm{~m}^{-2}$. A drainage and water storage sheet made of recycled polyethylene Floradrain FD25-E was placed over the polypropylene sheet, having a volume of approximately $10 \mathrm{~m}^{-2}$. The resulting structure was then covered with a polypropylene geo-textile, followed by a substrate of Floral Zincoterra. The substrate thickness was $11 \pm 1 \mathrm{~cm}$ and the total system thickness was approximately $15 \mathrm{~cm}$. The ZinCo Floral substrate was composed mainly of brick fragments with organic matter making up approximately $10 \%$ of its content (Zinco, 2010). Apparent density of the substrate was $90 \%$, with a total porosity of $66 \%$, pH values ranged between 7.95 and 8.08 and electrical conductivity values ranged from 158.4 to $194.2 \mu \mathrm{S} / \mathrm{cm}$ (microSiemens $/ \mathrm{cm}$ ). Porosity and density levels were calculated in the laboratory using samples from the substrate, while $\mathrm{pH}$ and electrical conductivity were measured every three months using a laboratory $\mathrm{pH}$ meter. 


\subsection{Plants}

Twelve species were selected according to their ecological and structural characteristics (see Table 2) and their availability in commercial nurseries. The flora of different environments was taken into consideration, including rocky environments, dunes, and dry coastal areas. The flora of conglomerate soils were also examined, as well as surfaces without an edaphic layer such as walls and cliffs (Caneva et al., 2013). Species were classified according to three different growth-forms: ground cover, sub-shrub, and rhizomatous-herbaceous. Such a classification is mainly related to the morphological behaviour of plants growing in a Mediterranean environment, although some species can display different features in different environments due to phenotypic plasticity.

Table 2. Selected species: ecological and structural information

\begin{tabular}{|c|c|c|c|c|}
\hline Species & Botanic family & Chorotype & Environment & Growth form \\
\hline Armeria maritima (P. Mill.) Willd. & Plumbaginaceae & Sub-cosmopolita & $\begin{array}{l}\text { Coastal areas, dry environment, } \\
\text { sandy soils, marshland }\end{array}$ & Rhizomatous-herbaceous \\
\hline Asteriscus maritimus (L.) Less. & Compositae & W. Medit. & Rocky coastal Sandy like soils & Sub-shrub \\
\hline Centranthus ruber (L.) DC. & Valerianaceae & Steno Medit. & Calcareous and rocky soils & Sub-shrub \\
\hline Dymondia margaretae Compton & Asteraceae & South Africa & Sandy coastal soils & Ground cover \\
\hline $\begin{array}{l}\text { Drosanthemum floribundum (Haw.) } \\
\text { Schwantes }\end{array}$ & Aizoaceae & South Africa & $\begin{array}{l}\text { Cultivated and sub-spontaneous in } \\
\text { Mediterranean area }\end{array}$ & Sub-shrub \\
\hline Frankenia laevis $\mathrm{L}$. & Frankeniaceae & $\begin{array}{l}\text { Steno Medit.-Central } \\
\text { Asia South Africa }\end{array}$ & Sandy coastal soils and marshland & Ground cover \\
\hline Helichrysum stoechas (L.) Moench & Compositae & W. Medit. & Sandy, rocky dry soils & Sub-shrub \\
\hline Iris lutescens Lam. & Iridaceae & NW-Steno-Medit. & Dry and rocky fields & Rhizomatous-herbaceous \\
\hline Limonium virgatum (Willd.) Fourr. & Plumbaginaceae & Euri-Medit. & Costal retro dunes and salty cliffs & Rhizomatous-herbaceous \\
\hline Lotus creticus L. & Leguminosae & Steno Medit. & $\begin{array}{l}\text { Coastal sandy soils and dune } \\
\text { systems environments }\end{array}$ & Sub-shrub \\
\hline Santolina rosmarinifolia $\mathrm{L}$. & Compositae & W. Medit. North Africa & $\begin{array}{l}\text { Dry rocky, sandy, conglomerate } \\
\text { like soils }\end{array}$ & Sub-shrub \\
\hline Thymus serpyllum* ${ }^{*}$. & Labiatae & Euri-Medit. & $\begin{array}{l}\text { Arid grasslands, rocky soils and } \\
\text { mesophytic forest borders }\end{array}$ & Sub-shrub/ground cover \\
\hline
\end{tabular}

Note. *Differential behavior due to phenotypic plasticity.

\subsection{Experimental Design and Irrigation}

The experimental design consisted of a split-plot: the main influencing factor was irrigation, with the application of three different irrigation protocols; the second influencing factor was plant species; twelve different species were included in the experiment. Three plots were planted for each irrigation protocol for a total of nine plots. Each of the nine main plots had a surface area of $12 \mathrm{~m}^{2}$ and was divided into twelve sub-plots of $1 \mathrm{~m}^{2}$ each. Nine plants of a single species were planted in each sub-plot resulting in a density of nine plants per square meter. The placement of the twelve species was the same for every plot in each irrigation protocol. Three different irrigation protocols were used: rain fed (no use of artificial irrigation, $0 \%$ ET0); replenishment of $20 \%$ of water lost to potential evapotranspiration ( $20 \%$ ET0); and replenishment of $40 \%$ of the same (40\% ET0). The quantity of water supplied was calculated on a weekly basis, taking into account the previous week's data and subtracting the total amount of precipitation from the total value of ET0 (evapotranspiration minus rainfall). The resulting amount of water was distributed evenly throughout the week. The water distribution system was composed of drip emitting tubes placed on the surface with a diameter of $16 \mathrm{~mm}$, and a $30 \mathrm{~cm}$ space between tubes, with a flow rate of $22.8 \mathrm{litres} / \mathrm{m}^{2} /$ hour. Over the whole period of the trial, $216 \mathrm{litres} / \mathrm{m}^{2}$ of water were supplied to the 40 $\%$ ET0 sub-plots and 108 litres $/ \mathrm{m}^{2}$ to the $20 \%$ ET0 sub-plot; the average weekly values were, respectively, 4.9 and 2.5 litres $/ \mathrm{m}^{2}$ for the two irrigation protocols. The water supplied during the hottest months (from June to September) was 184 litres for the $40 \%$ ET0 irrigation protocol and 92 litres for the $20 \%$ ET0 protocol, equivalent 
to $85 \%$ of the total water supplied throughout the year.

\subsection{Green Roof Performance and Measures}

The following parameters were measured: mortality, coverage, timing, duration and percentage of flowering, and hypogeal and epigeal biomass. The results for each species were analysed according to their functional group and to the irrigation protocol assigned to them. The survival rate of the plants was measured each month; frequency and duration of flowering were recorded every fifteen days. Plants lacking leaves and living branches were considered dead and left in situ. Flowering was recorded throughout the trial period. In order to evaluate the entire flowering period of a plant the duration and number of flowering branches were recorded. The number of flowering branches was also recorded as a percentage of the total number of branches on a single plant. With regard to coverage, the experimental system was photographed every two months, from a height of $2.5 \mathrm{~m}$ with a Nikon EOS 500 camera using Nikon EOS specific software. Photographs were taken around midday (11 am - 2 $\mathrm{pm}$ ) in order to reduce the effect of shadows. The camera was placed on a tripod equipped with a horizontal extendable arm. All photographs were taken from the same distance and height, and the same image and camera settings were used. Images were then processed with the Greenpix software (developed by the Institut de Recerca i Tecnologia Agroalimentàries - IRTA), for the analysis of digital images (Casadesús et al., 2005, 2007). A Hue range of 0 to 180 was used, making it possible to identify the number of yellow, brown and green pixels, and to calculate the percentage of each color portion in relation to the total image pixels, and to transform the pixels into $\mathrm{cm}^{2}$ for an evaluation of total cover (green, yellow and brown). With regard to the plant growth parameter, only the green surface corresponding to pixels within the 60-180 Hue range was taken into account. The evaluation of biomass was carried out by sorting the different species according to location and to irrigation protocol. All plants were then carefully separated from the earth In some cases portions of roots were sifted out from the substrate. Finally, the epigeal parts (leaves and stalk) were separated from the roots. The roots were rinsed thoroughly with water, and all plants were placed in a paper bag allowing permeation of air and humidity. All plant material was then dried in an oven for a period of seven days at $65^{\circ} \mathrm{C}$ before being weighed.

\subsection{Statistical Analysis}

An experiment was designed to measure the following factors: irrigation, species, and sampling. In order to study the spread of the coverage area for each species, the ANOVA mixed models statistical analysis was applied using the sampling and irrigation factors as fixed data, and the block as a variable factor; three levels were set for the irrigation factor, eight for the sampling factor, and three for the block factor. To determine significant outcome differences between the irrigation protocols and the sampling schedule, a post hoc test was applied using Tukey adjustments. The same analysis was carried out by grouping the species according to their growth form. Biomass analysis for each species was carried out using ANOVA mixed models, setting a fixed variable (irrigation protocol) and a random variable (block). The overall analysis was conducted using version 9.2 of the SAS software. For each irrigation protocol plot, mean biomass and mean coverage, both according to growth form, were compared using the Tukey Kramer HSD test and version 10 of the JMP software.

\section{Results}

\subsection{Plant Mortality}

Average mortality results of each growth form are reported in Table 3: mortality rates of all species, categorised by irrigation protocol, are shown in Figure 1. It can be seen that the mortality rate of Asteriscus maritimus, Drosanthemum floribundum and Lotus creticus was above $81 \%$ in winter, regardless of the irrigation protocol applied. The remaining species to which water was supplied artificially resulted in a mortality rate ranging from $0 \%$ to $38 \%$, whereas the species in the rain fed group showed mixed results: Asteriscus maritimus, Drosanthemum floribundum, Lotus creticus and Dymondia margaretae had an almost 100\% mortality rate; Frankenia laevis and Limonium virgatum had a mortality rate of $70 \%$ and $74 \%$ respectively; Thymus serpyllum 48\%; Helichrysum stoechas 37\%; the mortality rates of Armeria maritima, Centranthus ruber, Iris lutescens and Santolina rosmarinifolia were between $14 \%$ and $18 \%$.

\subsection{Coverage}

Coverage values of each species were categorised according to irrigation protocol and to growth form. The results of each group's coverage performance throughout the trial are shown in Table 4. Table 5 shows total averages and significant differences: all growth form groups displayed significant differences in terms of coverage when comparing the irrigated plots with the rain fed plot. Irrigated plants reached greater coverage in May and November; the lowest values were recorded in March. The results of each species were as follows (Figure 2): Armeria maritima, Iris lutescens and Santolina rosmarinifolia showed steady growth without 
seasonal variation. Thymus serpyllum, Frankenia laevis, Limonium virgatum and Centranthus ruber are the species that performed best in the irrigated protocols when the trial was completed, despite showing seasonal variations. The worst final results, irrespective of irrigation protocol, were recorded for Asteriscus maritimus, Lotus creticus and Drosanthemum floribundum. In the rain fed protocol Centranthus ruber, Helichrysum stoechas and Limonium virgatum showed the best results.
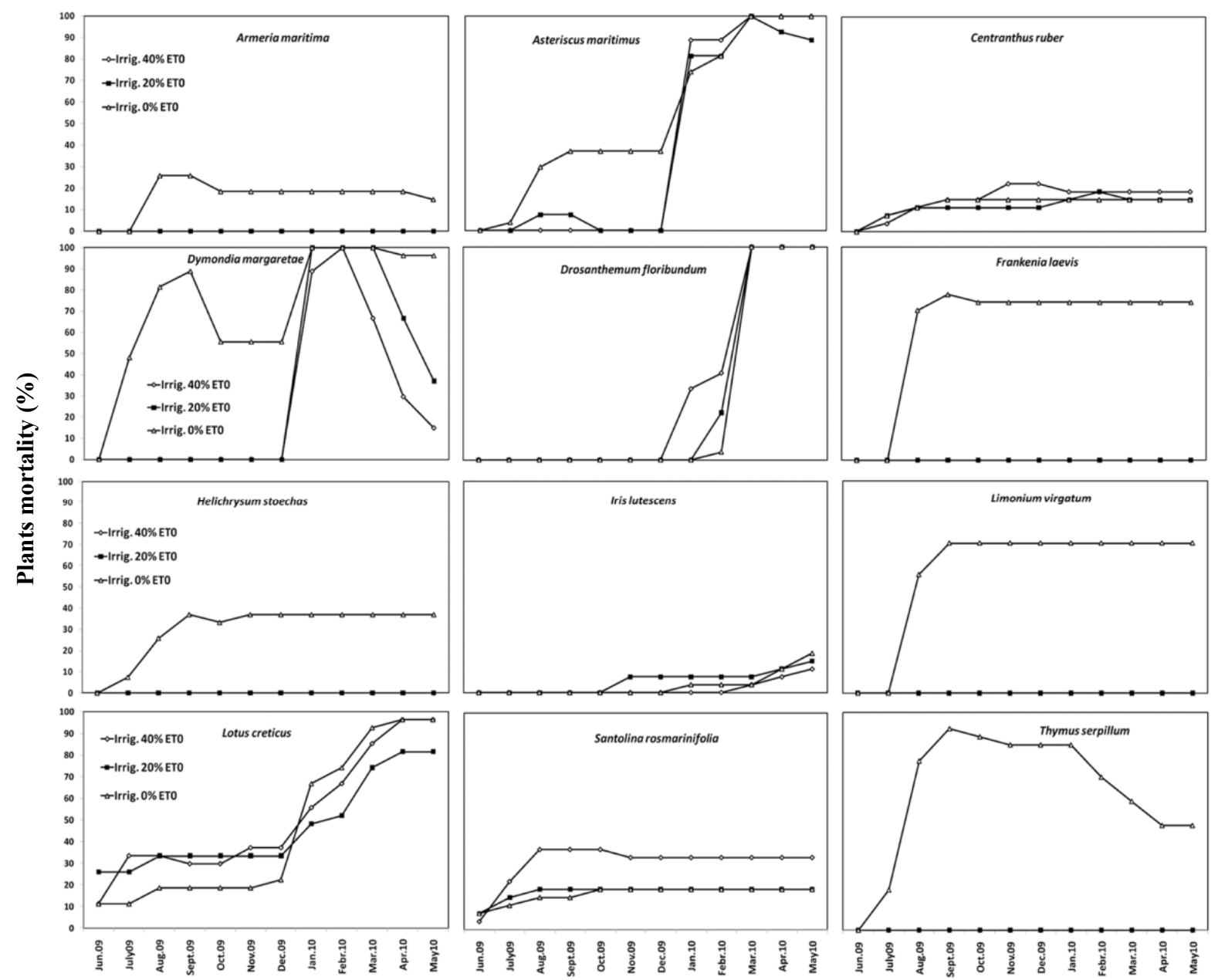

Figure 1. Mortality rate of species from June 2009 to May 2010 according to rain fed (0\% ET0), $20 \%$ ET0 and $40 \%$ ET0 irrigation protocols 


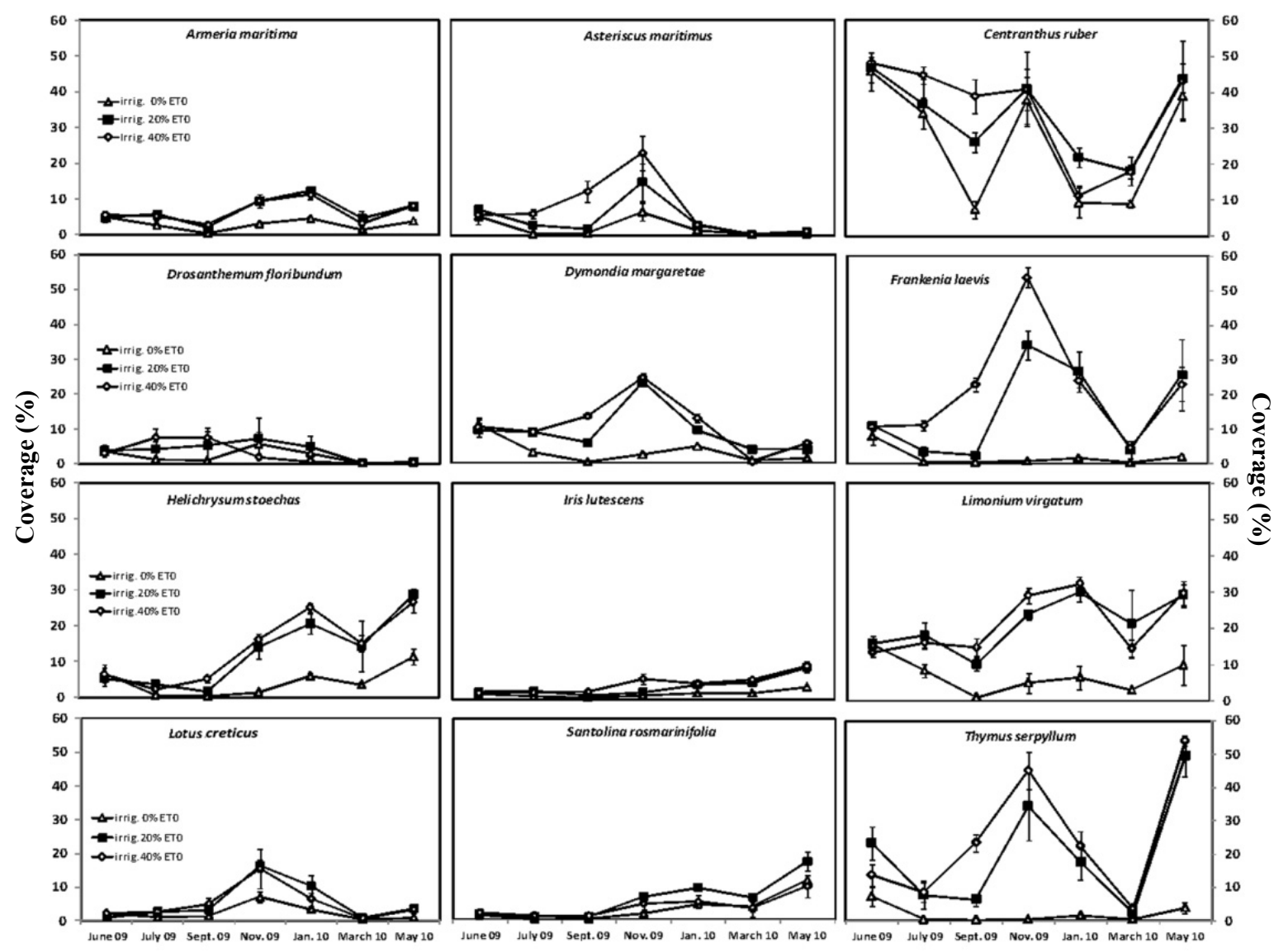

Figure 2. Green cover from June 2009 to May 2010 according to the different irrigation protocols $0 \%, 20 \%$, and $40 \%$ of ET0. Final values are the result of 3 mean values \pm standard error 
Table 3. Summary of plant mortality by percentage ( \pm standard error) for three irrigation treatments $0 \%, 20 \%, 40 \%$ ET0 (average figures for all values under the same irrigation protocol) and for three life-form groups (sub-shrubs, ground cover, rhizomatous-herbaceous) categorized by irrigation protocol $0 \%, 20 \%, 40 \%$ ET0

\begin{tabular}{|c|c|c|c|c|c|c|}
\hline \multicolumn{7}{|c|}{$\%$ Plants Mortality } \\
\hline Date & $\begin{array}{l}\text { Irrigation } 0 \% \\
\text { ETO }\end{array}$ & $\begin{array}{l}\text { Irrigation } 20 \% \\
\text { ET0 }\end{array}$ & $\begin{array}{l}\text { Irrigation } 40 \% \\
\text { ETO }\end{array}$ & $\begin{array}{l}\text { Sub-shrubs } \\
\text { irrigation 0\% ET0 }\end{array}$ & $\begin{array}{l}\text { Sub-shrubs } \\
\text { irrigation } 20 \% \text { ET0 }\end{array}$ & $\begin{array}{l}\text { Sub-shrubs } \\
\text { irrigation } 40 \% \text { ET0 }\end{array}$ \\
\hline June 2009 & $1.54 \pm 1.06$ & $2.78 \pm 2.19$ & $1.23 \pm 0.95$ & $2.65 \pm 1.75$ & $4.76 \pm 3.68$ & $2.12 \pm 1.59$ \\
\hline July 2009 & $8.95 \pm 3.96$ & $4.01 \pm 2.39$ & $4.94 \pm 3.17$ & $8.47 \pm 2.24$ & $6.88 \pm 3.83$ & $8.47 \pm 5.16$ \\
\hline Aug. 2009 & $34.26 \pm 8.51$ & $5.86 \pm 3.04$ & $6.79 \pm 3.94$ & $25.40 \pm 9.47$ & $10.05 \pm 4.69$ & $11.64 \pm 6.28$ \\
\hline Sept. 2009 & $39.81 \pm 9.79$ & $5.86 \pm 3.04$ & $6.79 \pm 3.81$ & $30.69 \pm 11.45$ & $10.05 \pm 4.69$ & $11.64 \pm 6.02$ \\
\hline Oct. 2009 & $35.80 \pm 8.61$ & $5.25 \pm 3.07$ & $6.79 \pm 3.81$ & $30.16 \pm 10.83$ & $8.99 \pm 4.91$ & $11.64 \pm 6.02$ \\
\hline Nov. 2009 & $35.80 \pm 8.44$ & $5.86 \pm 3.04$ & $7.72 \pm 4.14$ & $30.16 \pm 10.40$ & $8.99 \pm 4.91$ & $13.23 \pm 6.46$ \\
\hline Dec. 2009 & $36.11 \pm 8.38$ & $5.86 \pm 3.04$ & $7.72 \pm 4.14$ & $30.69 \pm 10.31$ & $8.99 \pm 4.91$ & $13.23 \pm 6.46$ \\
\hline Jan. 2010 & $46.91 \pm 10.12$ & $22.53 \pm 10.11$ & $26.54 \pm 9.92$ & $42.33 \pm 12.52$ & $23.28 \pm 11.68$ & $32.80 \pm 11.97$ \\
\hline Feb. 2010 & $47.22 \pm 9.95$ & $25.00 \pm 9.95$ & $29.01 \pm 10.79$ & $42.86 \pm 12.12$ & $27.51 \pm 11.14$ & $35.45 \pm 12.60$ \\
\hline Mar. 2010 & $57.41 \pm 10.75$ & $34.57 \pm 12.84$ & $33.95 \pm 12.10$ & $60.32 \pm 14.27$ & $43.92 \pm 17.29$ & $48.15 \pm 17.24$ \\
\hline April 2010 & $57.10 \pm 10.51$ & $32.10 \pm 11.67$ & $32.10 \pm 12.09$ & $59.26 \pm 14.59$ & $43.92 \pm 17.10$ & $49.74 \pm 17.87$ \\
\hline May 2010 & $57.41 \pm 10.39$ & $29.63 \pm 11.06$ & $31.17 \pm 12.13$ & $59.26 \pm 14.59$ & $43.39 \pm 16.85$ & $49.74 \pm 17.87$ \\
\hline Date & $\begin{array}{l}\text { Ground cover } \\
\text { irrigation } 0 \% \\
\text { ETO }\end{array}$ & $\begin{array}{l}\text { Ground cover } \\
\text { irrigation } 20 \% \\
\text { ETO }\end{array}$ & $\begin{array}{l}\text { Ground cover } \\
\text { irrigation } 40 \% \\
\text { ETO }\end{array}$ & $\begin{array}{l}\text { Rhizomatou-herb } \\
\text { aceous irrigation } \\
\text { 0\% ETO }\end{array}$ & $\begin{array}{l}\text { Rhizomatou-herba } \\
\text { ceous irrigation } \\
20 \% \text { ET0 }\end{array}$ & $\begin{array}{l}\text { Rhizomatous-herba } \\
\text { ceous irrigation } \\
40 \% \text { ETO }\end{array}$ \\
\hline June 2009 & $0.00 \pm 0.00$ & $0.00 \pm 0.00$ & $0.00 \pm 0.00$ & $0.00 \pm 0.00$ & $0.00 \pm 0.00$ & $0.00 \pm 0.00$ \\
\hline July 2009 & $22.22 \pm 14.02$ & $0.00 \pm 0.00$ & $0.00 \pm 0.00$ & $0.00 \pm 0.00$ & $0.00 \pm 0.00$ & $0.00 \pm 0.00$ \\
\hline Aug. 2009 & $76.54 \pm 3.27$ & $0.00 \pm 0.00$ & $0.00 \pm 0.00$ & $27.16 \pm 16.05$ & $0.00 \pm 0.00$ & $0.00 \pm 0.00$ \\
\hline Sept. 2009 & $86.42 \pm 4.45$ & $0.00 \pm 0.00$ & $0.00 \pm 0.00$ & $32.10 \pm 20.55$ & $0.00 \pm 0.00$ & $0.00 \pm 0.00$ \\
\hline Oct. 2009 & $72.84 \pm 9.64$ & $0.00 \pm 0.00$ & $0.00 \pm 0.00$ & $29.63 \pm 21.06$ & $0.00 \pm 0.00$ & $0.00 \pm 0.00$ \\
\hline Nov. 2009 & $71.60 \pm 8.64$ & $0.00 \pm 0.00$ & $0.00 \pm 0.00$ & $29.63 \pm 21.06$ & $2.47 \pm 2.47$ & $0.00 \pm 0.00$ \\
\hline Dec. 2009 & $71.60 \pm 8.64$ & $0.00 \pm 0.00$ & $0.00 \pm 0.00$ & $29.63 \pm 21.06$ & $2.47 \pm 2.47$ & $0.00 \pm 0.00$ \\
\hline Jan. 2010 & $86.42 \pm 7.51$ & $33.33 \pm 33.33$ & $29.63 \pm 29.63$ & $30.86 \pm 20.21$ & $2.47 \pm 2.47$ & $0.00 \pm 0.00$ \\
\hline Feb. 2010 & $81.48 \pm 9.32$ & $33.33 \pm 33.33$ & $33.33 \pm 33.33$ & $30.86 \pm 20.21$ & $2.47 \pm 2.47$ & $0.00 \pm 0.00$ \\
\hline Mar. 2010 & $77.78 \pm 11.91$ & $33.33 \pm 33.33$ & $22.22 \pm 22.22$ & $30.86 \pm 20.21$ & $2.47 \pm 2.47$ & $1.23 \pm 1.23$ \\
\hline April 2010 & $72.84 \pm 13.91$ & $22.22 \pm 22.22$ & $9.88 \pm 9.88$ & $33.33 \pm 18.64$ & $3.70 \pm 3.70$ & $2.47 \pm 2.47$ \\
\hline May 2010 & $72.84 \pm 13.91$ & $12.35 \pm 12.35$ & $4.94 \pm 4.94$ & $34.57 \pm 17.93$ & $4.94 \pm 4.94$ & $3.70 \pm 3.70$ \\
\hline
\end{tabular}


Table 4. Summary of coverage by percentage ( \pm standard error) for three irrigation protocols $0 \%, 20 \%, 40 \%$ ET0 (average figure for all values of the same treatment) and three life-form groups for each irrigation protocol $0 \%$, $20 \%, 40 \%$ ET0 (sub-shrubs, ground cover, rhizomatous- herbaceous)

\begin{tabular}{|c|c|c|c|c|c|c|}
\hline \multicolumn{7}{|c|}{ Coverage \% } \\
\hline Date & $\begin{array}{l}\text { Irrigation } 0 \% \\
\text { ET0 }\end{array}$ & $\begin{array}{l}\text { Irrigation } 20 \% \\
\text { ET0 }\end{array}$ & $\begin{array}{l}\text { Irrigation } 40 \% \\
\text { ET0 }\end{array}$ & $\begin{array}{l}\text { Sub-shrubs } \\
\text { irrigation 0\% ET0 }\end{array}$ & $\begin{array}{l}\text { Sub-shrubs } \\
\text { irrigation } 20 \% \text { ETO }\end{array}$ & $\begin{array}{l}\text { Sub-shrubs } \\
\text { irrigation } 40 \% \text { ET0 }\end{array}$ \\
\hline June 09 & $10.42 \pm 3.52$ & $12.12 \pm 3.72$ & $11.35 \pm 3.64$ & $10.91 \pm 0.87$ & $13.57 \pm 6.27$ & $12.38 \pm 6.16$ \\
\hline July 09 & $4.72 \pm 2.76$ & $8.93 \pm 2.91$ & $10.66 \pm 3.39$ & $5.55 \pm 4.76$ & $8.78 \pm 4.71$ & $11.16 \pm 5.73$ \\
\hline Sept. 09 & $1.25 \pm 0.57$ & $6.07 \pm 2.03$ & $14.03 \pm 3.36$ & $1.72 \pm 0.96$ & $6.73 \pm 3.31$ & $14.60 \pm 5.11$ \\
\hline Nov. 09 & $6.72 \pm 2.95$ & $21.49 \pm 3.78$ & $25.65 \pm 5.08$ & $9.45 \pm 4.90$ & $21.26 \pm 4.72$ & $23.63 \pm 6.55$ \\
\hline Jan. 10 & $4.73 \pm 0.77$ & $15.58 \pm 2.38$ & $14.66 \pm 2.86$ & $4.80 \pm 1.10$ & $13.70 \pm 2.70$ & $11.43 \pm 3.42$ \\
\hline Mar. 10 & $2.43 \pm 0.80$ & $7.59 \pm 2.06$ & $6.30 \pm 1.82$ & $2.94 \pm 1.34$ & $6.78 \pm 2.85$ & $6.28 \pm 2.76$ \\
\hline May 10 & $8.30 \pm 3.22$ & $20.06 \pm 4.80$ & $19.27 \pm 4.84$ & $10.87 \pm 5.38$ & $22.40 \pm 7.76$ & $20.86 \pm 8.04$ \\
\hline Date & $\begin{array}{l}\text { Ground cover } \\
\text { irrigation } 0 \% \\
\text { ET0 }\end{array}$ & $\begin{array}{l}\text { Ground cover } \\
\text { irrigation } 20 \% \\
\text { ET0 }\end{array}$ & $\begin{array}{l}\text { Ground cover } \\
\text { irrigation } 40 \% \\
\text { ET0 }\end{array}$ & $\begin{array}{l}\text { Rhizomatous-herba } \\
\text { ceous irrigation } 0 \% \\
\text { ET0 }\end{array}$ & $\begin{array}{l}\text { Rhizomatous-herbac } \\
\text { eous irrigation } 20 \% \\
\text { ET0 }\end{array}$ & $\begin{array}{l}\text { Rhizomatous-herbac } \\
\text { eous irrigation } 40 \% \\
\text { ET0 }\end{array}$ \\
\hline June 09 & $11.10 \pm 3.51$ & $16.58 \pm 3.57$ & $13.83 \pm 1.92$ & $4.55 \pm 1.10$ & $16.25 \pm 7.04$ & $16.81 \pm 7.82$ \\
\hline July 09 & $2.02 \pm 1.55$ & $8.72 \pm 3.32$ & $11.48 \pm 1.81$ & $4.05 \pm 2.17$ & $9.09 \pm 4.51$ & $8.01 \pm 4.02$ \\
\hline Sept. 09 & $0.43 \pm 0.08$ & $6.13 \pm 2.11$ & $22.92 \pm 0.27$ & $2.39 \pm 0.48$ & $11.11 \pm 5.14$ & $8.79 \pm 3.25$ \\
\hline Nov. 09 & $1.76 \pm 1.14$ & $35.69 \pm 1.48$ & $46.58 \pm 3.82$ & $6.41 \pm 1.81$ & $17.27 \pm 6.23$ & $17.63 \pm 6.32$ \\
\hline Jan. 10 & $3.71 \pm 2.10$ & $19.97 \pm 3.36$ & $22.63 \pm 0.72$ & $3.23 \pm 0.97$ & $12.09 \pm 6.13$ & $15.90 \pm 6.56$ \\
\hline Mar. 10 & $0.64 \pm 0.28$ & $4.17 \pm 1.21$ & $2.99 \pm 1.17$ & $7.54 \pm 4.03$ & $7.94 \pm 4.01$ & $7.24 \pm 3.18$ \\
\hline May 10 & $2.72 \pm 0.60$ & $27.15 \pm 2.39$ & $28.75 \pm 13.17$ & $0.69 \pm 0.17$ & $4.56 \pm 2.78$ & $6.96 \pm 3.92$ \\
\hline
\end{tabular}

Table 5. Summary of percentage of coverage for three irrigation protocols $0 \%, 20 \%, 40 \%$ ET0 (average figure for all values of the same treatment) and three life-form groups for each irrigation protocol 0\%, 20\%, 40\% ET0 (sub-shrubs, ground cover, rhizomatous-herbaceous). Average figures not associated with the same letter are significantly different at $\mathrm{p}<0.05$ (TEST TUKEY KRAMER HSD)

\begin{tabular}{|c|c|c|c|c|c|c|c|c|c|c|c|}
\hline \multicolumn{3}{|c|}{ Irrigation } & \multicolumn{3}{|c|}{ Sub-shrubs } & \multicolumn{3}{|c|}{ Ground cover } & \multicolumn{3}{|c|}{ Rhizomatous-herbaceous } \\
\hline 0\% ETO & 4.64 & B & 0\% ETO & 6.60 & B & 0\% ETO & 3.19 & B & 0\% ETO & 4.12 & B \\
\hline $20 \%$ ETO & 13.80 & $\mathbf{A}$ & $20 \% \mathrm{ETO}$ & 13.31 & $\mathbf{A}$ & $20 \% E T 0$ & 16.91 & $\mathbf{A}$ & $20 \% \mathrm{ETO}$ & 11.18 & $\mathbf{A}$ \\
\hline $40 \%$ ETO & 15.75 & $\mathbf{A}$ & $40 \%$ ETO & 14.33 & $\mathbf{A}$ & $40 \%$ ETO & 21.30 & $\mathbf{A}$ & $40 \%$ ETO & 11.62 & $\mathbf{A}$ \\
\hline
\end{tabular}

\subsection{Flowering}

Most species flowered during the Summer of 2009 and Spring of 2010 (see Table 6). The only species that presented differences in the duration of its flowering period between one irrigated plot and another was Thymus serpyllum, which flowered until October in the $40 \%$ ET0 protocol plots, two months longer than the plants in the 20\% ET0 protocol plots; and Asteriscus maritimus which flowered an additional month when being watered with the $40 \%$ ET0 system compared to plants in the $20 \%$ ET0 protocol plots. Lotus creticus and Santolina rosmarinifolia did not flower at all, whereas Frankenia laevis, (butonly the plants in the 20\% ET0 protocol plots)presented limited flowering in May. Dymondia margaretae flowered only in August. Asteriscus maritimus, Centranthus ruber, Helichrysum stoechas, Limonium virgatum and Thymus serpyllum presented limited flowering in terms of time and quantity in the rain fed plots when compared to the plants in the irrigated plots. 
Table 6. Flowering periods of the trial species for three different irrigation protocols: $0 \%$ ET0, 20\% ET0 and $40 \%$ ET0

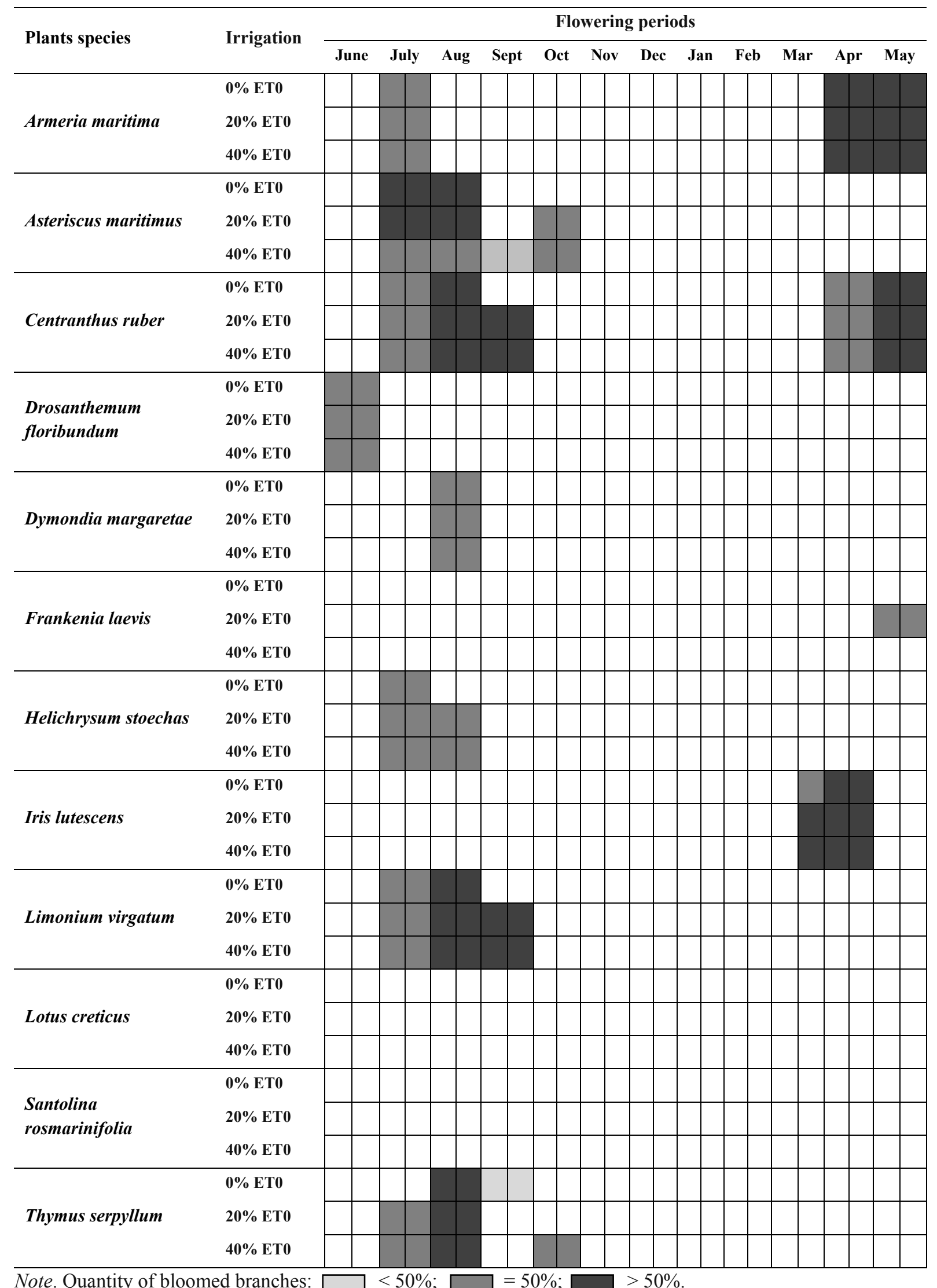




\subsection{Biomass}

In all growth forms, the biomass of the upper portion was greater than that of the root system; all groups presented significant differences in biomass production when comparing the irrigated plots to the rain fed plots, with the exception of the roots of rhizomatous-herbaceous. No group displayed significant differences in biomass production between the two irrigation protocols (20\% and $40 \%$ ET0) (Table 7). Table 8 shows the average biomass values of each species and its portions (shoot system, root system, and total biomass) and the ratio between root system and shoot system for each irrigation protocol. Only nine out of the twelve species were used for this analysis, because the remaining three (Asteriscus maritimus, Drosanthemum floribundum, Lotus creticus) had an insufficient biomass for sampling. Sampling of Dymondia margaretae was performed only for the plants in the irrigated plots, because all plants in the rain fed plots died. Of the nine species recorded, five (Armeria maritima, Frankenia laevis, Helichrysum stoechas, Iris lutescens and Thymus serpyllum) displayed significant differences between shoot system and total biomass. Centranthus ruber, Limonium virgatum and Santolina rosmarinifolia did not display any significant differences between irrigation protocols in terms of epigeal development. Four species developed a significantly greater root system biomass for the irrigated plants than for the rain fed plants: Armeria maritima, Dymondia margaretae, Frankenia laevis, Helichrysum stoechas and Thymus serpyllum. For Limonium virgatum, there was a significant difference between root system biomass values in the rain fed and $20 \%$ ET0 protocol plots and those in the $40 \%$ ET0 protocol plots.

Table 7. Average for $\mathrm{g}( \pm$ standard error) of the different fragments and total dry biomass $(\mathrm{g})$ of the plants under three irrigation protocols $0 \%, 20 \%, 40 \%$ ET0 (average figure for all values of the same treatment), and of the three life-form groups for each irrigation protocol $0 \%, 20 \%, 40 \%$ ET0 (sub-shrubs, ground cover, rhizomatous-herbaceous). Average figures not associated with the same letter are significantly different $(\mathrm{p}<0.05)$ (TEST TUKEY KRAMER HSD)

\begin{tabular}{|c|c|c|c|c|}
\hline \multicolumn{5}{|c|}{ BIOMASS } \\
\hline \multicolumn{5}{|l|}{ Irrigation } \\
\hline & $\mathrm{N}^{\mathrm{o}}$ & Shoot system & Root system & Total \\
\hline $0 \%$ ET0 & 138 & $24.11 \pm 2.30 \mathrm{~b}$ & $6.61 \pm 0.62 b$ & $30.72 \pm 2.55 b$ \\
\hline $20 \%$ ET0 & 222 & $39.50 \pm 1.82 \mathrm{a}$ & $8.94 \pm 0.49 \mathrm{a}$ & $48.36 \pm 2.01 \mathrm{a}$ \\
\hline $40 \%$ ET0 & 219 & $40.79 \pm 1.83 \mathrm{a}$ & $8.57 \pm 0.49 \mathrm{a}$ & $49.37 \pm 2.02 \mathrm{a}$ \\
\hline \multicolumn{5}{|c|}{ Sub-shrubs } \\
\hline & $\mathrm{N}^{\mathrm{o}}$ & Shoot system & Root system & Total \\
\hline $0 \% \quad$ ET0 & 80 & $27.95 \pm 2.80 \mathrm{~b}$ & $8.12 \pm 0.89 b$ & $36.07 \pm 3.51 \mathrm{~b}$ \\
\hline $20 \%$ ET0 & 99 & $45.20 \pm 2.52 \mathrm{a}$ & $11.60 \pm 0.80 \mathrm{a}$ & $56.68 \pm 3.16 \mathrm{a}$ \\
\hline $40 \%$ ET0 & 93 & $40.92 \pm 2.60 \mathrm{a}$ & $10.42 \pm 0.82 \mathrm{ab}$ & $51.34 \pm 3.26 \mathrm{a}$ \\
\hline \multicolumn{5}{|c|}{ Ground cover } \\
\hline & $\mathrm{N}^{\mathrm{o}}$ & Shoot system & Root system & Total \\
\hline 0\% ЕT0 & 26 & $4.79 \pm 4.92 \mathrm{~b}$ & $0.71 \pm 0.88 b$ & $5.50 \pm 4.76 \mathrm{~b}$ \\
\hline $20 \%$ ET0 & 73 & $29.80 \pm 2.94 \mathrm{a}$ & $6.88 \pm 0.52 \mathrm{a}$ & $36.69 \pm 2.84 \mathrm{a}$ \\
\hline $40 \%$ ET0 & 77 & $34.21 \pm 2.86 \mathrm{a}$ & $7.81 \pm 0.51 \mathrm{a}$ & $42.03 \pm 2.77 \mathrm{a}$ \\
\hline \multicolumn{5}{|c|}{ Rhizomatous-herbaceous } \\
\hline & $\mathrm{N}^{\mathrm{o}}$ & Shoot system & Root system & Total \\
\hline $0 \%$ ЕT0 & 51 & $19.64 \pm 3.76 b$ & $4.96 \pm 0.92 \mathrm{a}$ & $24.60 \pm 3.75 b$ \\
\hline $20 \%$ ET0 & 77 & $37.55 \pm 3.06 \mathrm{a}$ & $7.07 \pm 0.75 \mathrm{a}$ & $44.53 \pm 3.05 \mathrm{a}$ \\
\hline $40 \%$ ET0 & 76 & $44.56 \pm 3.08 \mathrm{a}$ & $6.37 \pm 0.75 \mathrm{a}$ & $50.93 \pm 3.07 \mathrm{a}$ \\
\hline
\end{tabular}


Table 8. Average dry weight (g) of the trial species under three irrigation protocols ( $40 \%$ ET0, 20\% ET0, and $0 \%$ ET0). Average figures not associated with the same letter are significantly different $(\mathrm{p}<0.05)$

\begin{tabular}{|c|c|c|c|c|c|}
\hline Plants species & Irrigation & Shoot system (g) & Root system (g) & Total (g) & Root/Shoot \\
\hline \multirow[t]{3}{*}{ Armeria maritima } & $0 \%$ ET0 & $13.64 \mathrm{~b}$ & $1.31 \mathrm{~b}$ & $14.96 \mathrm{~b}$ & $0.1 \mathrm{a}$ \\
\hline & $20 \%$ ET0 & $26.14 \mathrm{a}$ & $3.04 \mathrm{a}$ & $29.17 \mathrm{a}$ & $0.1 \mathrm{a}$ \\
\hline & $40 \%$ ET0 & $27.97 \mathrm{a}$ & $2.88 \mathrm{a}$ & $30.85 \mathrm{a}$ & $0.1 \mathrm{a}$ \\
\hline \multirow[t]{3}{*}{ Centranthusruber } & $0 \%$ ET0 & $46.61 \mathrm{a}$ & $17.97 \mathrm{a}$ & $64.58 \mathrm{a}$ & $0.4 \mathrm{a}$ \\
\hline & $20 \%$ ET0 & $56.94 \mathrm{a}$ & $20.05 \mathrm{a}$ & $76.99 \mathrm{a}$ & $0.4 \mathrm{a}$ \\
\hline & $40 \%$ ET0 & $49.86 \mathrm{a}$ & $20.10 \mathrm{a}$ & $69.96 \mathrm{a}$ & $0.4 \mathrm{a}$ \\
\hline \multirow[t]{3}{*}{ Dymondia margaretae } & $0 \%$ ET0 & & & & \\
\hline & $20 \%$ ET0 & $8.11 \mathrm{~b}$ & $8.47 \mathrm{~b}$ & $16.57 \mathrm{a}$ & $1.0 \mathrm{a}$ \\
\hline & $40 \%$ ET0 & $2.83 \mathrm{a}$ & $13.13 \mathrm{a}$ & $15.96 \mathrm{a}$ & $4.6 \mathrm{a}$ \\
\hline \multirow[t]{3}{*}{ Frankenia laevis } & $0 \%$ ET0 & $12.92 \mathrm{c}$ & $1.35 \mathrm{~b}$ & $14.27 \mathrm{~b}$ & $0.1 \mathrm{~b}$ \\
\hline & $20 \%$ ET0 & $46.19 \mathrm{~b}$ & $4.91 \mathrm{a}$ & $51.10 \mathrm{a}$ & $0.1 \mathrm{~b}$ \\
\hline & $40 \%$ ET0 & $62.10 \mathrm{a}$ & $4.50 \mathrm{a}$ & $66.60 \mathrm{a}$ & $0.1 \mathrm{a}$ \\
\hline \multirow[t]{3}{*}{ Helichrysu stoechas } & $0 \%$ ET0 & $29.99 \mathrm{~b}$ & $5.40 \mathrm{~b}$ & $35.39 \mathrm{~b}$ & $0.2 \mathrm{a}$ \\
\hline & $20 \%$ ET0 & $52.32 \mathrm{a}$ & $9.53 \mathrm{a}$ & $61.84 \mathrm{a}$ & $0.2 \mathrm{a}$ \\
\hline & $40 \%$ ET0 & $50.36 \mathrm{a}$ & $8.83 \mathrm{a}$ & $59.19 \mathrm{a}$ & $0.2 \mathrm{a}$ \\
\hline \multirow[t]{3}{*}{ Iris lutescens } & $0 \%$ ET0 & $12.46 \mathrm{~b}$ & 8.88 a & $21.34 \mathrm{~b}$ & $0.7 \mathrm{a}$ \\
\hline & $20 \%$ ET0 & $18.66 \mathrm{ab}$ & $14.37 \mathrm{a}$ & $33.03 \mathrm{ab}$ & $0.8 \mathrm{a}$ \\
\hline & $40 \%$ ET0 & $26.35 \mathrm{a}$ & $14.08 \mathrm{a}$ & $40.43 \mathrm{a}$ & $0.5 \mathrm{a}$ \\
\hline \multirow[t]{3}{*}{ Limonium virgatum } & 0\% ET0 & $50.14 \mathrm{a}$ & $6.04 \mathrm{a}$ & $56.18 \mathrm{a}$ & $0.1 \mathrm{c}$ \\
\hline & $20 \%$ ET0 & $65.25 \mathrm{a}$ & $5.32 \mathrm{a}$ & $70.56 \mathrm{a}$ & $0.1 \mathrm{~b}$ \\
\hline & $40 \%$ ET0 & $76.01 \mathrm{a}$ & $3.59 \mathrm{~b}$ & $79.60 \mathrm{a}$ & $0.0 \mathrm{a}$ \\
\hline \multirow[t]{3}{*}{ Santolina rosmarinifolia } & $0 \%$ ET0 & $29.53 \mathrm{a}$ & $6.44 \mathrm{a}$ & $35.97 \mathrm{a}$ & $0.2 \mathrm{a}$ \\
\hline & $20 \%$ ET0 & $44.98 \mathrm{a}$ & $9.93 \mathrm{a}$ & $54.91 \mathrm{a}$ & $0.2 \mathrm{a}$ \\
\hline & $40 \%$ ET0 & $26.85 \mathrm{a}$ & $6.50 \mathrm{a}$ & $33.35 \mathrm{a}$ & $0.2 \mathrm{a}$ \\
\hline \multirow[t]{3}{*}{ Thymus serpyllum } & 0\% ET0 & $1.79 \mathrm{~b}$ & $0.48 \mathrm{~b}$ & $2.27 \mathrm{~b}$ & $0.3 \mathrm{a}$ \\
\hline & $20 \%$ ET0 & $28.65 \mathrm{a}$ & $7.76 \mathrm{a}$ & $36.41 \mathrm{a}$ & $0.3 \mathrm{a}$ \\
\hline & $40 \%$ ET0 & $33.04 \mathrm{a}$ & $6.60 \mathrm{a}$ & $39.64 \mathrm{a}$ & $0.2 \mathrm{a}$ \\
\hline
\end{tabular}

\section{Discussion}

\subsection{Mortality}

Two main factors affected plant mortality: the amount of water received and the low winter temperatures. The mortality rate of all rain fed species rose during the trial. Irrigated plants experienced a higher mortality rate in January than in other months due to low temperatures.

\subsection{Coverage}

As shown in the literature, the growth form and morphology of a plant affect the interception of rain by the substrate as well as its thermal and hydrological characteristics (Del Barrio, 1998; Dunnett et al., 2008; Nagase \& Dunnett, 2012; Mentens et al., 2005; Buccola \& Spolek, 2010; Scott MacIvor et al., 2011; Olivieri et al., 2013). In this trial the sub-shrub form was shown to be affected by low temperatures more than other forms; ground cover species suffered more than others from drought; and rhizomatous-herbaceous plants were the least affected by drought and cold weather. 
Green cover had two growth peaks, in autumn and spring, corresponding to typical seasonal changes in the Mediterranean climate. In these seasons the increased availability of rainwater associated with low evapotranspiration can reduce the importance of irrigation. In spring and autumn the rain fed plants (grouped by species or by growth form) extended their percentage of coverage, achieving higher growth rates than those in the irrigated plots, although they did not exceed a maximum value of $11 \%$; a better performance may be advantageous if they are to be used in green roofs. Some species, despite low final coverage, developed slowly and constantly, showing that the speed of coverage development and the colonisation of ecological niches varies for each species; this depends mostly on stress tolerance and ecological characteristics (Benvenuti, 2014). In order to obtain greater cover with those species which displayed low development, it is advisable to use higher plant density.

Notable differences in terms of coverage arise only when comparing rain fed plots with irrigated plots (regardless of the specific irrigation protocol applied). The results of this study did not achieve the official requirements established for temperate climate countries, which require a minimum coverage of $80 \%$ of the total surface (FLL, 2008) after the initial period. Given requirements are not always applicable in a Mediterranean environment, thermal and rainfall conditions are very different in the Mediterranean area compared to Northern Europe (Van Mechelen et al., 2014). In this study, irrigated ground cover species achieved higher coverage values compared to other growth forms, this could be due to morphological difference in these plants. The development of ground cover plants was mainly horizontal and they produced root systems which allowed them to spread out and multiply; sub-shrubs developed mainly in volume. Rhizomatous-herbaceous and sub-shrubs displayed minor seasonal variations and achieved lower coverage values compared to the ground cover plants. All rain fed plots resulted in a lower percentage of coverage. In order to reach a wider coverage as quickly as possible, and to achieve ornamental heterogeneity, all three growth forms should be used, with a prevalence of ground cover plants.

\subsection{Flowering}

Irrigation influenced the flowering of five species. The flowering period of rain fed plants, in some cases, was delayed or ended early, and they displayed a lower percentage of flowering branches. In Mediterranean environments plants often flower in spring, and occasionally a new outbreak is expected in autumn. The evaluation of the percentage of flowering branches for each plant and of their flowering period makes it possible to analyse responses to stress conditions, but these parameters do not include the size of the plant, making it difficult to carry out a complete aesthetic evaluation. This study provides information about species which are able to produce flowers in conditions of little to no artificial watering. The results also suggest that irrigation could be required in order to obtain even minimal flowering on Mediterranean green roofs, due to the severe summer drought.

\subsection{Biomass}

Final average biomass values back up most of the parameters analysed: no significant difference arises between results from the two irrigation protocols. The experimental settings may have been responsible for the fact that significant differences appeared only when comparing irrigated plots with rain fed plots: it is not possible to detect a difference in outcomes between the two minimal irrigation protocols, although it is possible to compare their results with the rain fed outcome. A study carried out in a Mediterranean-Australian climatic zone obtained similar results: plants with similar irrigation protocols did not present any difference in their final biomass (Williams et al., 2010). In terms of species, five out of nine displayed significant differences in total biomass values, and four species also displayed significant differences in their root systems between irrigated and rain fed plots. The ratio between root biomass and upper portions did not present significant differences between one irrigation protocol and another, apart from two species (Frankenia laevis e Limonium virgatum), suggesting that biomass was distributed homogeneously between roots and upper parts. On the other hand, a study carried out by Farrell et al. (2013) on the possibility of using species which grow on a thin granite substrate, observed that most species responded to water shortages by increasing the supply to the roots and reduced their leaf surface area.

\subsection{Species}

The analysis of single species shows that Centranthus ruber employs a strategy that causes a reduction of the shoot system during winter and a greater vegetative growth in spring, coinciding with the season where no water was supplied although the reduced water supply in summer affected coverage, which decreased in plants receiving $20 \%$ of ET0 and in rain fed plants. Flowering also suffered a negative effect in rain fed plants, whose flowering duration was shortened by one month. A study carried out in Tuscany, Italy (Benvenuti \& Bacci, 2010) using Centranthus ruber on an igroperlite ${ }^{\circledR}$ substrate at different depths $(15 \mathrm{~cm}$ and $20 \mathrm{~cm})$, obtained a coverage 
of $62 \%$ and $100 \%$ respectively. This species is well adapted to Mediterranean conditions. The high mortality rate of rain fed Frankenia laevis, and variations in its coverage throughout the seasons, show the high dependence of this species on irrigation. Armeria maritima and Iris lutescens developed slowly, reaching minimal coverage values which remained consistent throughout the trial. Nevertheless, their mortality rate was low, making their use in green roofs advisable: increasing the density of initial planting could compensate for reduced growth. Provenzano et al. (2010), in a study carried out in Italy, confirmed these same results for Armeria maritima, for which they obtained a coverage of $40 \%$ along with a low growth rate on an $8 \mathrm{~cm}$ deep irrigated substrate, where the ground humidity was lower than $20 \%$. Santolina rosmarinifolia and Helichrysum stoechas showed high adaptability to the Mediterranean climate, presenting little variation in coverage and low mortality rates. The growth rate of Santolina rosmarinifolia was not improved by the water supply, as opposed to Helichrysum stoechas. Papafotiou et al. (2013) have observed that two species of Helichrysum, tested with limited irrigation, were found to be appropriate for mediterranean green roofs. Thymus serpyllum, when irrigated, reached high coverage values of about $50 \%$. This growth performance has been confirmed by two separate studies: Provenzano et al. (2010), in a Mediterranean environment, on an $8 \mathrm{~cm}$ deep substrate, reported coverage of $85 \%$ some months after winter transplanting; in Japan a trial was conducted on a $10 \mathrm{~cm}$ deep substrate, receiving 5 litres of water every two days, the coverage increased by more than $70 \%$ between May and September, reaching a final value of $90 \%$ (Takahiro et al., 2010). In this trial, rain fed plants reached $4 \%$ coverage. Irrigated plants benefitted in terms of flowering, mortality and coverage (mainly during the summer), this species therefore seems to rely on watering. Rain fed Dymondia margaretae did not tolerate drought, resulting in high mortality rates in summer, whereas irrigated plants of this species did not tolerate low temperatures (their leaves dried). However, it presented good vegetative growth over the following spring. This is the only species in which the root system biomass exceeded that of the shoot system; growth was limited and flowering scarce. Mortality for Asteriscus maritimus, Lotus creticus and Drosanthemum floribundum was caused by low winter temperatures, regardless of the irrigation protocol - meaning that the water supplied throughout the trial did not improve resistance. Irrigated plants of the Limonium virgatum species had a $100 \%$ survival rate, and little variation in flowering and coverage; growth was constant throughout the trial. Rain fed plants had a reduced flowering period (one month less compared to irrigated plants). The rosette plant structure does not allow rapid extension in coverage. However, the ability to produce viable seeds, their germination, and the survival of seedlings demonstrated efficient adaptation to the Mediterranean climate.

\section{Conclusion}

This study shows that some species can be used with minimal irrigation for green roofs in the Mediterranean area. The results provide indications on growth form functionality: different growth form groups responded in different ways to stresses of different seasons. Rhizomatous-herbaceous developed slowly and consistently; ground cover plants developed quickly and relied more on the water supply; sub-shrubs showed lower resistance to stresses under the present experimental conditions. Centranthus ruber, Santolina rosmarinifolia, Helichrysum stoechas and Iris lutescens performed well under the experimental conditions; the performance of Limonium virgatum, Armeria maritima, Frankenia laevis and Thymus serpyllum was good, although the results are dependent on minimal irrigation (growth in Armeria maritima and Iris lutescens was slower than in other species); Asteriscus maritimus, Lotus creticus, Drosanthemum floribundum and Dymondia margaretae failed to adapt to the experimental conditions of this trial. This study is a useful tool for the selection of plants for use in Mediterranean green roofing, providing information on survival and the development of plant types and species. An appropriate mixture of all three growth forms could be an interesting subject for future investigation, especially in relation to the amount of water required.

\section{Acknowledgements}

This paper shows partial results developed in the frame of CUMED project, which has been partially economically supported by MINECO of Spanish Government.

\section{References}

Abram, P. (2006). Il verde pensile in Italia e in Europa. Milano: Il Verde Editoriale.

Abram, P. (2011). Verde pensile. Pozzuoli: Sistemi Editoriali SE.

Agencia de Ecología Urbana de Barcelona. (2010). Cobertes i Murs Verds a Barcelona. Estudi sobre les existentes, el potencial $i$ les estratègies de implantació. Retrieved from http://bcnecologia.net/sites/default/files/proyectos/doc_cobertes_i_murs_verds_01m2010_0.pdf

Ajuntament de Barcelona. (2010). Els corredors verds urbans. Exemples i criteris de disseny. Área de Medi 
Ambient

Retrieved

from http:/www.sostenibilitatbcn.cat/attachments/article/123/CorredorsVerdsUrbans.pdf

Andersson, E. (2006). Urban landscapes and sustainable cities. Ecology and Society, 11(34). Retrieved from http://www.ecologyandsociety.org/vol11/iss1/art34/

Benvenuti, S., \& Bacci, D. (2010). Initial agronomic performances of Mediterranean xerophytes in simulated dry green roofs. Urban Ecosystems, 13, 349-363. http://dx.doi.org/10.1007/s11252-010-0124-129

Benvenuti, S. (2014). Wildflower green roofs for urban landscaping, ecological sustainability and biodiversity. Landscape and Urban Planning, 124, 151-161. http://dx.doi.org/10.1016/j.landurbplan.2014.01.004

Bass, B. (2009). Biodiversity Research Protocol. Green Roofs for Healthy Cities - Draft Biodiversity Research Protocol. Retrieved from http://www.greenroofs.org/resources/Biodiversity_Research_on_Green_Roofs Protocol_2009.pdf

Brennesein, S. (2006). Space for Urban Wildlife: Designing Green Roofs as Habitats in Switzerland. Urban Habitats, 4(1), 27-36.

Bretzel, F., Pezzarossa, B., Benvenuti, S., Bravi, A., \& Malorgio, F. (2011). Soil influence on the performance of 26 native herbaceous plants suitable for sustainable Mediterranean landscaping. Acta Oecologica, 35, 657-663. http://dx.doi.org/ 10.1016/j.actao.2009.06.008

Britz-Escribano, J. (2004). Naturación urbana y mejora medioambiental: Cubiertas ecológicas. Madrid: Mundi-prensa Libros.

Buccola, N., \& Spolek, G. (2011). A Pilot-Scale Evaluation of Greenroof Runoff Retention, Detention, and Quality. Water Air Soil Pollution, 216, 83-92. http://dx.doi.org/10.1007/s11270-010-0516-8

Caneva, G., Kumbaric, A., Savo, V., \& Casalini, R. (2013). Ecological approach in selecting extensive green roof plants: A data set of Mediterranean plants. Plant Byosystem, 1-10. http://dx.doi.org/10.1080/11263504.2013.819819

Carter, T., \& Butler, C. (2008). Ecological impacts of replacing traditional roofs with green roofs in two urban areas. Cities and the Environment, 1(2), 1-17.

Casadesús, J., Biel, C., \& Savé, R. (2005). Turf color measurement with conventional digital cameras. Proceedings of EFITA/WCCA Joint Congress: On it in Agriculture 25-28 July 2005, Vila Real, Portugal.

Casadesus, J., Kaya, Y., Bort, J., Nachit, M. M., Araus, J. L., Amor, S., ... Villegas, D. (2007). Water Use Efficiency. Using vegetation indices derived from conventional digital cameras as selection criteria for wheat breeding in water-limited environments. Ann. Appl. Biol., 150, 227-236. http://dx.doi.org/10.1111/j.1744-7348.2007.00116.x

Damas, O., Donvez, J., Ferrando, D., Ferre, A., Marqueyssat, P., \& Delhommeau, P. (2010). Identification of plant ranges adapted to water limited conditions of green roofs: A case study from France. Proceedings of World Green Roof Congress: Green roofs for a changing climate, 15-16 September 2010, London, UK.

Del Barrio, E. P. (1998). Analysis of the green roofs cooling potential in buildings. Energy and Buildings, 27, 179-193. http://dx.doi.org/10.1016/S0378-7788(97)00029-7

Dunnett, N., Nagase, A., Booth R., \& Grime, P. (2008). Influence of vegetation composition on runoff in two simulated green roof experiments. Urban Ecosystems, 11(4), 385-398. http://dx.doi.org/10.1007/s11252-008-0064-9

Farrell, C., Szota, C., Williams, N. S., \& Arndt, S. K. (2013). High water users can be drought tolerant: using physiological traits for green roof plant selection. Plant Soil, 372(1-2), 177-193. http://dx.doi.org/10.1007/s11104-013-1725-x

FLL, German Landscape Research, Development and Construction Society. (2008). Guidelines for the Planning, Construction and Maintenance of Green Roofing. Bonn, Germany.

Gedge, D., \& Kadas, G. (2005). Green roofs and biodiversity. Biologist, 52(3), 161-169.

Köhler, M. (2006). Long-Term Vegetation Research on Two Extensive Green Roofs in Berlin. Urban Habitats, 4(1), 3-27. Retrieved from http://www.urbanhabitats.org

Lundholm, J. (2006). Green roofs and facades: A habitat template approach. Urban Habitats, 4(1), 87-101.

Lundholm, J., \& Peck, S. W. (2008). Introduction: Frontiers of green roof ecology. Urban Ecosystems, 11, 
335-337. http://dx.doi.org/10.1007/s11252-008-0070-y

Lundholm, J., MacIvor, J. S., MacDougall, Z., \& Ranalli, M. (2010). Plant Species and Functional Group Combinations Affect Green Roof Ecosystem Functions. PLoS ONE, 5(3), http://dx.doi.org/10.1371/journal.pone.0009677

Mentens, J., Raes, D., \& Hermy, M. (2005). Green roofs as a tool for solving the rainwater runoff problem in the urbanized 21st century? Landscape Urban Planning, $217-226$. http://dx.doi.org/10.1016/j.landurbplan.2005.02.010

Nagase, A., \& Dunnett, N. (2010). Drought tolerance in different vegetation types for extensive green roofs: Effects of watering and diversity. Landscape and Urban Planning, 97, 318-327. http://dx.doi.org/10.1016/j.landurbplan.2010.07.005

Nagase, A., \& Dunnett, N. (2012). Amount of water runoff from different vegetation types on extensive green roofs: Effects of plant species, diversity and plant structure. Landscape and Urban Planning, 104, $356-363$. http://dx.doi.org/10.1016/j.landurbplan.2011.11.001

Neila, F. J., Bedoya, C., Acha, C., Olivieri, F., \& Barbero, M. (2008). Las cubiertas ecológicas de tercera generación: un nuevo material constructivo. Informes de la Construcción, 60, 15-24.

Oberndorfer, E., Lundholm, J., Bass, B., Coffman, R. R., Doshi, H., Dunnett, N., ... Rowe, B. (2007). Green roofs as urban ecosystems: Ecological structures, functions, and services. BioScience, 57(10), 823-834. http://dx.doi.org/10.1641/B571005

Olivieri, F., Di Perna, C., D’Orazio, M., Olivieri, L., \& Neila, J. (2013) Experimental measurements and numerical model for the summer performance assessment of extensive green roofs in a Mediterranean coastal climate. Energy and Buildings, 63, 1-14. http://dx.doi.org/10.1016/j.enbuild.2013.03.054

Papafotiou, M., Pergialioti, N., Tassoula, L., Massas, I., \& Kargas, G. (2013). Growth of Native Aromatic Xerophytesin an Extensive Mediterranean GreenRoof as Affected by Substrate Typeand Depth and Irrigation Frequency. Hortscience, 48(10), 1327-1333.

Provenzano, M. E., Cardarelli, M., Crasso, M., \& Colla, G. (2010). Evaluation of potential green roof plant species in a Mediterranean climate. Proceedings of World Green Roof Congress: Green roofs for a changing climate, 15-16 September 2010, London, UK.

Samangooei, M. (2006). Green spaces in the sky. What role do green roofs play in a Twenty-first century city? (Dissertation). Department of Architecture. Oxford Brookes University. Oxford.

Scott MacIvor, J., Ranalli, M. A., \& Lundholm, J. (2011). Performance of dryland and wetland plant species on extensive green roofs. Annals of Botany, 107, 671-679. http://dx.doi.org/ 10.1093/aob/mcr007

Spala, A., Bagiorgas, H. S., Assimakopoulos, M. N., Kalavrouziotis, J., Matthopoulos, D., \& Mihalakakou, G. (2008). On the green roof system. Selection, state of the art and energy potential investigation of a system installed in an office building in Athens, Greece. Renewable Energy, 33(1), 173-177. http://dx.doi.org/10.1016/j.renene.2007.03.022

So-Young, P., Jin-Su, S., Hyoung-Deug, K., Kenji, Y., \& Ki-Cheol, S. (2008). Effects of Interior Plantscapes on Indoor Environments and Stress Level of High School Students. Journal of the Japanese Society for Horticultural Science, 77(4), 447-454. http://dx.doi.org/10.2503/jjshs1.77.447

Takahiro, S., Michio, K., Yuichi, U., \& Noboru, I. (2010). Evaluation of Growth and Green Coverage of Ten Ornamental Species for Planting as Urban Rooftop Greening. Journal of the Japanese Society for Horticultural Science, 79(1), 69-76. http://dx.doi.org/10.2503/jjshs1.79.69

Van Mechelen, C., Dutoit, T., \& Hermy, M. (2014). Mediterranean open habitat vegetation offers great potential for extensive green roof design. Landscape and Urban Planning, 121, 81-91. http://dx.doi.org/10.1016/j.landurbplan.2013.09.010

Williams, N. S. G., Hughes, R. E., Jones, N. M., Bradbury, D. A., \& Rayner, J. P. (2010). In G. P. Gianquinto \& F. Orsini (Ed.), The Performance of Native and Exotic Species for Extensive Green Roofs in Melbourne, Australia (Acta Hort. 881). Procedings of the $\mathrm{II}^{\text {nd }}$ International Conf. on Landscape and Urban Hort.

$\begin{array}{llllll}\text { ZinCo. } & \text { (2010). } & \text { Retrieved } & \text { January } & \text { 22, } & \text { from }\end{array}$ http://www.zincogreenroof.com/EN/downloads/pdfs/ZinCo_Product_List.pdf 


\section{Copyrights}

Copyright for this article is retained by the author(s), with first publication rights granted to the journal.

This is an open-access article distributed under the terms and conditions of the Creative Commons Attribution license (http://creativecommons.org/licenses/by/3.0/). 